\title{
JUURNAL_RU
}

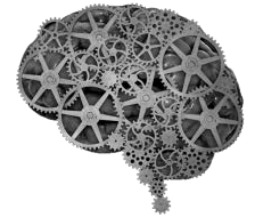

COMPANY GROUP "INTELLEKT"

\author{
Родионов С.И. \\ Липеикий государственный педагогический университет \\ Липеик, Россия
}

doi: 10.18411/lj2016-7-1-17

idsp 000001: lj2016-16-1-17

\section{Виды административного ареста и их правовое регулирование в России XIX века}

Аннотация: В статье рассматриваются особенности правового регулирования и исполнения административного ареста в Российской империи $\mathrm{X} 1 \mathrm{X}$ в. Отмечается, что наиболее применяемым был административный арест, опыт применения которого заслуживает внимания и современного законодателя.

Ключевые слова: административный арест, полиция, задержание, Устав, Инструкция, условия, закон, нарушитель.

Арест как мера государственного принуждения стал регулироваться на системном уровне в российском законодательстве сравнительно поздно, а именно начиная со второй половины X1X в., когда в результате судебной реформы и соответствующего изменения административного, уголовного и уголовно-процессуального права полицейский арест достаточно четко стал разделяться на три составляющие: 1) арест как мера административного принуждения; 2) арест как мера уголовно-процессуального принуждения; 3) арест как мера наказания (административного и уголовного) [1, с. 84].

Арест как административно-предупредительную меру применяли такие различные правоохранительные органы, как полиция и суд, Данная разновидность полицейского ареста занимала решающее место во властных полномочиях полиции в сфере охраны общественного порядка, и представляла собой такое личное задержание, поводами для которого служили не административные проступки или уголовные преступления, установленные в 
надлежащем порядке, когда заранее известен конкретный правонарушитель, а действия или поведение лиц, угрожающих общественной безопасности или общественной нравственности [2].

Эта мера находила отражение в Уставе о предупреждении и пресечении преступлений, который был сформирован в Своде законов Российской империи в 1832 г., после чего в него вносились изменения, и мы используем поэтому последнюю редакцию [3]. Этим законом полиции предписывалось, в частности, арестовывать нищих, по поводу которых в ст. 159 Устава указывалось: «Строго запрещается нищенствовать или бродить в городах, посадах, селениях, на ярмарках, больших и торговых дорогах, для исспрашивания и подаяния». Следует обратить внимание, что подобные нормы имели место и в первые годы советской власти [4, с. 169].

Законодатель в Уставе о предупреждении и пресечении преступлений предписывал также полиции задерживать: сопротивляющихся законным требованиям полицейских; пьяных, нарушающих общественную тишину, а также тех из них, которые «ночью не в указанные часы ходят и в пьяном виде шатаются»; публичных женщин, страдающих заразными болезнями (с последующей отправкой их в госпиталь); тех людей, на которых будут кричать «караул» в случае причинения побоев. Помимо этого, согласно Приложению к Уставу о предупреждении и пресечении преступлений полиция обязывается «задерживать людей, которые будут возить по тротуарам тележки, сани, или ходить по тротуарам с громоздкими тяжестями» (п. 1 Приложения).

Далее, полиция должна была также «если заметит, что кто-либо выходит из дому с узлами, задержать такого подозрительного человека, и выяснить, не случилось ли в доме кражи. Если подозрение окажется неосновательным, то задержанного отпустить, а в противном случае представить участковому приставу» (п. 3 Приложения). Равным образом это касалось случая, если «дозор в позднее время встретит человека, имеющего потаенную при себе ношу, или какой-либо узел, чемодан и тому подобное» (п. 4 Приложения). В другом законе - Уставе о паспортах (здесь также используется последняя редакция) [5] содержатся основания для полицейского ареста, исходя из особенностей регулируемых данным Уставом общественных отношений. 
В частности, согласно ст. 233 Устава предписывается задерживать лиц, пытающихся пересечь таможенную границу без паспорта. В категории лиц, которых должны были задерживать полицейские органы, относились также те, кто приговаривался к административному выселению на основании решении сельских обществ, волостных правлений, что свидетельствовало о серьезных полномочиях органов местного самоуправления [6, с. 77]. Задерживаемые в порядка полицейского ареста препровождались в арестные помещения. В этой связи отметим, что в 1866 году были приняты Временные правила для содержания лиц, подвергаемых аресту по приговорам мировых судей, которые вошли впоследствии в Свод учреждений и уставов о содержащихся под стражею. Туда же были включены изданные в развитие закона от 1866 года Правила о помещениях для подвергаемых аресту, Инструкция об устройстве арестных помещений, Инструкция попечителям и смотрителям арестных домов [7, c. 19].

Помещения для ареста устраивались земствами, соответственно и заведывание принадлежало уездной земской управе (ст. 1,2 Временных правил). Арестантам дозволялось, в частности, иметь собственный стол; они находились в собственной одежде, казенная выдавалась лишь по необходимости $($ ст.13,14). Из числа арестованных мещанам и крестьянам могла поручаться сдельная работа, при этом одна половина заработанных денег выдавалась на руки сразу, а вторая - по освобождении (ст.18). В случае привлечения арестантов на общественные работы "в замену особой платы день работы засчитывается ... за два дня ареста" (ст.19). Такого рода нормы позволяли соблюдать естественные права человека и стимулировали правопослушное поведение, однако, сразу заметим, в большинстве своем он не выполнялись [8, с. 85].

За неповиновение и неисполнение установленных правил виновные подвергались, по решению попечителя, следующим взысканиям: 1) выговор; 2) денежное взыскание не свыше 15 рублей; 3) заключение в комнату без света на время не свыше суток (ст.22). Представляют интерес требования, предъявляемые к оборудованию арестных помещений согласно Инструкции об устройстве помещений для лиц, подвергаемых аресту по приговору местного суда [9]. Так, согласно ст.1 Инструкции, арестные помещения должны находиться на сухой почве; окна должны быть обращены на солнечную сторону, а 
по близости его не должны находиться ни стоячая вода или болотистое место, ни какие-либо другие заведения или места, источающие зловредные испарения.

Внутреннее устройство помещения (полы, рамы, печи и др.) должны были находиться в исправности и, кроме того, должно было смотреть, чтобы из кухни не выходил дым и чад, а равно чтобы отхожие места не были очень отдалены от жилых покоев и не распространяли зловония (ст.2). Не допускались сложные системы глухих, темных, недоступных свежему воздуху коридоров (ст.3). В ст.7 говорилось о том, что "чем меньше будет помещено заключенных в одной комнате, тем лучше, но во всяком случае не следует помещать более 10 человек в одну комнату". Согласно ст.11 площадь, отводимая для каждого заключенного, с помещением на ней кровати и других вещей, должны быть не менее 65 кв. футов (около 18 кв. м.). Устройство нар запрещалось (ст.12). На каждые две кровати должно было предусматриваться не менее одного окна.

Следует заметить, что многие из этих требований и сейчас вполне могут конкурировать с современными нормами, в том числе регулирующими меры государственного принуждения [10, с. 21-28]. Но составители инструкции явно переоценили реальные возможности материальной базы тюремной системы России - в своей значительной части указанные правила воплощены не были [11, с. 59], и данное обстоятельство являлось характерным для тюремной системы России. 


\section{Литература:}

1. Курдюк П.М., Упоров И.В., Акопян А.В. Преступность как социальноопасное явление и государственное принуждение как метод его нейтрализации. Краснодар, 2007.

2. Историческое развитие уголовного права России. Агафонов Ю.А. Учеб. пособие / Ю.А. Агафонов, И.В. Упоров; М-во внутрен. дел Рос. Федерации. Краснодар. юрид. ин-т. Москва, 2003.

3. Устав о предупреждении и пресечении преступлений // Свод законов Российской империи. СПб., 1910. Т. 14.

4. Упоров И.В. Институт уголовного наказания в советском государстве начального периода // Журнал российского права. 2000. № 11. С.169.

5. 5. Устав о паспортах // Свод законов Российской империи. СПб., 1910. T.14.

6. Упоров И.В., Старков О.В. Муниципальное право Российской Федерации. Москва, 2015.

7. Уголовно-исполнительное право России / Под ред. А.И..Зубкова. М., 1997.

8. Рябченко Е.В., Рябченко А.Г., Упоров И.В., Кашоида В.В. Естественное право и особенности его закрепления в нормах позитивного права в России. Краснодар, 2004.

9. Сборник узаконеиий и распоряжений по тюремной части / Сост. Т.М.Лопато. Пермь, 1903. С.22-24.

10. Турицын И.В., Упоров И.В. Виды государственного принуждения, применяемого правоохранительными органами, и принципы его реализации // Право и практика. 2013. № 4. С. 21-28.

11. Медведева Н.Т., Упоров И.В. Истоки и развитие уголовного наказа-ния. Рязань, 1997. 